\title{
Factors influencing circulating OKT8 cell phenotypes in patients with multiple sclerosis
}

\author{
P J HUGHES,* P F KIRK,* J DYAS, $\dagger$ J A MUNRO, $\ddagger$ K I WELSH, \\ D A S COMPSTON*
}

From the Department of Neurology* and Tenovus Institute for Cancer Research, $\uparrow$ University of Wales College of Medicine, Cardiff, the Public Health Laboratory Service, $\ddagger$ University Hospital of Wales, Cardiff and the Tissue Typing Laboratory,§ Guy's Hospital, London, UK

SUMMARY Peripheral blood OKT8 cell phenotypes were correlated with measurements of plasma cortisol and serological evidence for exposure to 15 infectious agents, in longitudinal studies involving 13 patients with multiple sclerosis, 13 of their siblings, nine spouses and 13 unrelated controls; 44/48 individuals were HLA typed. Neither circadian rhythms, nor exposure to any one infectious agent accounted for the serial changes in OKT8 cells but there was an association between the presence of HLA-DR2 and periodic reductions in OKT8 cells irrespective of clinical status. Taken with previously reported serial observations in patients and cohabiting relatives, this finding provides indirect evidence for an interplay between environmental and genetic factors in determining OKT8 cell phenotypes in multiple sclerosis.

Serial observations indicate that a reduction in the number and percentage of circulating $\mathrm{T}$ cytotoxic/ suppressor lymphocytes occurs during chronic progressive stages of multiple sclerosis whereas correlations with disease activity during the relapsing phase are less clearcut. ${ }^{1-5}$ This discrepancy may reflect difficulty in assessing the onset of new lesions clinically, and result from methodological variations in measurement of $\mathrm{T}$ lymphocyte subpopulation phenotypes. ${ }^{6-8}$ Using standardised laboratory methods and samples collected from each individual at the same time of day, we found that OKT8 cell percentages and numbers were periodically reduced in cohabiting relatives of multiple sclerosis patients, ${ }^{9}$ and concluded that environmental conditions influence $T$ cell phenotypes in these individuals. Similar trends were observed in a second study involving some new individuals but owing to the use of different immunological reagents OKT8 cell phenotypes in patients and controls fell within a lower range so that the two studies were not directly comparable.

Genetic and environmental factors are implicated in the aetiology of multiple sclerosis, but probably interact in the sequence of events leading to tissue

Address for reprint requests: Dr D A S Compston, University of Wales College of Medicine, Heath Park, Cardiff CF44XN, UK.

Received 29 August 1986 and in revised form 7 January 1987. Accepted 19 January 1987 damage; it can therefore be difficult to dissociate their individual significance for the pathogenesis. In this study we have correlated HLA-DR type and serological evidence for exposure to 15 infectious agents, many previously implicated in the pathogenesis of multiple sclerosis, with OKT8 cell phenotypes observed serially within families. ${ }^{9}$

\section{Methods}

Samples of venous blood were taken from each of 13 patients with multiple sclerosis, 13 of their siblings, nine spouses and 13 unrelated healthy controls at weekly or fortnightly intervals between March and December 1983 and/or September and December 1984; 26 individuals participated only in the first, 13 only in the second and nine in both phases. Aliquots of unfractionated lymphocytes were used to enumerate $\mathrm{T}$ cell subpopulations as previously described; ${ }^{9}$ plasma cortisol was measured by a direct radioimmunoassay using a ${ }^{125} \mathrm{I}$ radioligand and a solid phase separation technique. ${ }^{10}$

\section{Antibodies to infectious agents}

Serum samples were stored at $-70^{\circ} \mathrm{C}$. Antibody titres against influenza $\mathbf{A}$ and $\mathbf{B}$, parainfluenza, adeno-, respiratory syncytial, varicellazoster, cytomegalo-, measles, herpes and mumps viruses, and psittacosis, Coxiella burnetti and mycoplasma were measured by complement fixation tests employing antigens supplied by the Division of Microbiological Reagents and Quality Control, (London, UK). Antibodies to rubella and Toxoplasma gondii were identified using an haemagglutination-inhibition test and enzyme 
linked immunosorbance assay (ELISA) IgG kit (Labsystems, Finland), respectively.

\section{HLA-DR phenotype}

The HLA-A, -B, -C, and -DR phenotypes were determined usng a two stage microcytotoxicity test ${ }^{11}$ typing antisera were obtained locally or donated by other laboratories and had been evaluated against the 12th Histocompatibility Workshop reagents.

\section{Statistical methods}

Each individual in the study was characterised by mean OKT8 cell percentage, the proportion of serial OKT8 cell observations that were judged to be low $(\leqslant 20 \%$ for phase I and $\leqslant 14 \%$ for phase $\mathrm{II}^{9}$; these have been analysed separately) and the mean of the logs of serial antibody titres. Comparisons between groups were performed using $t$ tests; only results of unpaired tests are reported although where a one-to-one direct correspondence existed between groups, the paired $t$ test was also performed and gave a similar result. Interpretation of $t$ values was 2-tailed and cautious in view of the multiplicity of comparisons performed.

\section{Results}

\section{Circadian rhythms}

The possibility that previously reported fluctuations in OKT8 cell phenotypes in multiple sclerosis patients and their close contacts were artefacts due to circadian rhythms in lymphocyte subpopulations, which vary inversely with plasma cortisol, ${ }^{8}$ was controlled by collecting samples between 7.30-10.30 am and always from each individual at the same time of day. Plasma cortisol was measured in 5-19 samples from each participant in both phases of the study; concentrations ranged from $46-1400 \mathrm{nmol} / \mathrm{l}$ and varied both within and between individuals but not in the two phases, so that the results were analysed together. There was no difference in cortisol concentration in multiple sclerosis patients, spouses, siblings and controls $(373 \pm 83 \cdot 5 ; 495 \pm 256 ; 444 \pm 196$ and 408 $\pm 288 \mathrm{nmol}$ respectively; $\mathrm{p}$ not significant). Plasma cortisol did not vary in any participant coinciding with periodic reductions in the OKT8 cell phenotype. The data are not shown in tables.

\section{Antibodies to infectious agents}

Serological observations involving all 15 infectious agents were made in 5-21 samples from each of 13 patients, nine spouses, 13 siblings and 13 controls, except for antibodies against rubella and Toxoplasma gondii which were measured in the first and last samples only; none of the eight individuals initially without detectable rubella antibody subsequently seroconverted. One patient with multiple sclerosis developed antibodies against Toxoplasma gondii between the two phases indicating recent exposure; antibody titres against all 14 remaining organisms varied between participants as expected, but there were no alterations in any one individual indicating recent exposure, or anamnestic responses. There were no changes in serological reactivity in multiple sclerosis patients or their relatives at the time of clinical relapse, or coinciding with periodic reductions in OKT8 cells. No differences were observed in mean log antibody titres against all organisms studied serially, including measles, between the four groups in either phase of the study. The data are not shown in tables.

\section{HLA-DR phenotype}

Forty four of 48 individuals were HLA-DR typed; the frequency of HLA-DR2 was increased in patients (6/11) compared with all other individuals (9/33). Since the results of $T$ lymphocyte phenotypes were not directly comparable between the two phases, associations between HLA-DR2 and OKT8 cell percentages have been assessed separately for each part of the study. There was a trend in favour of lower mean OKT8 cell percentages in all HLA-DR2 positive individuals irrespective of clinical classification, in each phase (table 1). This relationship could be an artefact arising from the independent association between HLA-DR2 and multiple sclerosis, but the trend towards an association between lower OKT8 cell percentages and HLA-DR2 was still observed when multiple sclerosis patients were excluded from analysis (table 2). Both results were more marked in the first than second phase of the study, and statistical significance was only attained in the former.

The results have also been assessed by combining the two phases and comparing the number of occasions on which reduced OKT8 cell phenotypes were observed. There was an association between HLADR2 and low OKT8 cell percentages in all individuals

Table 1 Mean OKT8 cell phenotypes (\%) in all individuals

\begin{tabular}{lcc}
\hline & $\begin{array}{l}\text { Mean T8 cells } \\
\text { phase } 1\end{array}$ & $\begin{array}{l}\text { Mean T8 cells } \\
\text { phase } 2\end{array}$ \\
\hline DR2 positive & $21.2 \pm 4.9$ & $15 \cdot 2 \pm 1 \cdot 7$ \\
DR2 negative & $26.0 \pm 3.3$ & $16.9 \pm 5.0$ \\
$t$ test & 3.02 & 1.12 \\
p value & $<0.01$ & $>0.1$ \\
\hline
\end{tabular}

Table 2 Mean OKT8 cell phenotypes (\%) in unaffected individuals

\begin{tabular}{lcl}
\hline & $\begin{array}{l}\text { Mean T8 cells } \\
\text { phase } 1\end{array}$ & $\begin{array}{l}\text { Mean T8 cells } \\
\text { phase 2 }\end{array}$ \\
\hline DR2 positive & $23.3 \pm 5.9$ & $16.1 \pm 0.2$ \\
DR2 negative & $26.7 \pm 2.4$ & $17.6 \pm 5.5$ \\
$l$ test & 1.37 & 0.95 \\
p value & $>0.1$ & $>0.1$ \\
\hline
\end{tabular}


Table 3 Number of low OKT8 cell observations (\%)

\begin{tabular}{|c|c|c|c|c|}
\hline & $\begin{array}{l}\text { All individuals } \\
n=44\end{array}$ & $\begin{array}{l}\text { All } \\
\text { unaffected individuals } \\
n=33\end{array}$ & $\begin{array}{l}\text { Spouses and } \\
\text { cohabiting siblings } \\
n=10\end{array}$ & $\begin{array}{l}\text { Non-cohabiting } \\
\text { siblings and controls } \\
n=23\end{array}$ \\
\hline $\begin{array}{l}\text { DR2 positive } \\
\text { DR2 negative }\end{array}$ & $\begin{array}{l}74 / 174(42 \%) \\
86 / 377(23 \%)\end{array}$ & $\begin{array}{l}29 / 92(31 \%) \\
55 / 317(17 \%)\end{array}$ & $\begin{array}{l}23 / 47(49 \%) \\
24 / 83(29 \%)\end{array}$ & $\begin{array}{c}6 / 45(13 \%) \\
31 / 234(13 \%)\end{array}$ \\
\hline
\end{tabular}

which was still observed after exclusion of multiple sclerosis cases (table 2). This was not an ascertainment artefact as similar numbers of replicate samples were taken from patients and members of other groups. In order further to assess the contribution of genetic and environmental factors in influencing $T$ cell phenotypes in these families, the number of low OKT8 cell percentages was compared in HLA-DR2 positive spouses and cohabiting siblings, who each had close contact with multiple sclerosis patients $(49 \%)$, and the remaining unaffected HLA-DR2 positive siblings and all controls $(13 \%)$. However, this difference was also observed in a similar comparison restricted to HLA-DR2 negative participants $(29 \%$ vs $13 \%)$. But there was a difference in the number of low OKT8 cell values between HLA-DR2 positive and negative spouses/cohabiting siblings $(49 \%$ vs $29 \%$; table 3). $\chi^{2}$ analysis has been avoided as the data are in the form of repeated observations in the same subjects.

\section{Discussion}

Previously we have shown that OKT8 positive cell numbers and percentages are reduced in patients with multiple sclerosis and their close contacts compared with relatives not living in the same household, or unrelated controls. ${ }^{9}$ In the present analysis, low OKT8 cell percentages were observed more frequently in samples from cohabitants of multiple sclerosis patients than other relatives or controls irrespective of HLA-DR type, further emphasising the influence of environmental conditions on the $T$ cell phenotypes. However, we have been unable to implicate any single organism in determining the changes in lymphocyte subpopulations. Antibody titres against 15 common infectious agents did not vary between or within individuals, or correlate with changes in OKT8 cell percentages. Therefore, if a single infectious agent is responsible it is probably not a common pathogen.

Genetic factors may also indirectly have influenced the periodic reductions in circulating OKT8 positive cells. There was an increased frequency of HLA-DR2, and reduction in OKT8 cell numbers in patients with multiple sclerosis so that these abnormalities may have a non-causal relationship even if each is independently associated with the disease. However, there was an association between DR2 and low OKT8 cell percentages even after excluding patients with multiple sclerosis from analysis, especially within the small group of close contacts of patients with the disease.

Taken together the results suggest an interplay between markers of genetic susceptibility and environmental conditions, in determining serial measurements of $T$ cell phenotypes within families; some influential factors are identified, such as HLA-DR2, whereas others are merely implicated by the epidemiological method. The available evidence suggests that no one risk factor appears necessary or is itself sufficient for the development of multiple sclerosis, but it is their occurrence in the same individual, perhaps in a special sequence or at critical times ${ }^{1213}$ which determines the development of the disease. It may be difficult further to disentangle the complex sequence of events which leads to tissue damage in multiple sclerosis using non-specific immunological methods and an indirect epidemiological approach, together with genetic markers which may not themselves be directly involved in regulating immune responses. Environmental and genetic theories on the cause of multiple sclerosis should not be regarded as alternatives; this study provides further evidence implicating their interaction in the pathogenesis of the disease.

\section{References}

1 Reinherz EL, Weiner HL, Hauser SL, Cohen JA, Diastaso JA, Schlossman SF. Loss of suppressor T cells in active multiple sclerosis-analysis with monoclonal antibodies. $N$ Engl J Med 1980;303:125-9.

2 Compston DAS. Lymphocyte subpopulations in patients with multiple sclerosis. J Neurol Neurosurg Psychiatry 1983;46:105-14.

3 Hauser SL, Reinherz EL, Hoban CJ, Schlossman SF, Weiner HL. Immunoregulatory $T$ cells and lymphocytotoxic antibodies in active multiple sclerosisweekly analysis over a six month period. Ann Neurol 1983;13:418-25.

4 Paty DW, Kastrukoff L, Morgan N, Hiob L. Suppressor T-lymphocytes in multiple sclerosis-analysis of patients with acute relapsing and chronic progressive disease. Ann Neurol 1983;14:445-9.

5 Rice GPA, Finney D, Braheny SL, Knobler RL, Sipe JC, Oldstone MBA. Disease activity markers in multiple 
sclerosis. Another look at suppressor cells defined by monoclonal antibodies OKT4, OKT5 and OKT8. $J$ Neuroimmunol 1984;6:75-84.

6 Thompson AJ, Brazil J, Martin EA, Hutchinson M, Whelan CA, Feighery C. Suppressor T cell changes in active multiple sclerosis: analysis with three different monoclonal antibodies. J Neurol Neurosurg Psychiatry 1985;48:1062-4.

7 Parry Jones H, Hughes PJ, Kirk P, Hoy T. T-cell subsets: effects of cryopreservation, paraformaldehyde fixation, incubation regime and choice of fluorescein-conjugated anti-mouse IgG on the percentage positive cells stained with monoclonal antibodies. J Immunol Methods 1986;92:195-200.

8 Ritchie AWS, Oswald I, Micklem HS, et al. Circadian variation of lymphocyte subpopulations: a study with monoclonal antibodies. $\mathrm{Br}$ Med J 1983;286:1773-5.

9 Hughes PJ, Kirk PF, Compston DAS. Suppressor T cells in family members of patients with multiple sclerosis. Brain 1986;109:969-85.

10 Riad-Fahmy D, Read GF, Gaskell SJ, Dyas J, Hindawi R. A simple, direct radioimmunoassay for plasma cortisol, featuring a ${ }^{125} \mathrm{I}$ radioligand and a solid phase separation technique. Clin Chem 1979;25:665-8.

11 Welsh KI, Batchelor JR. Assays for antibodies against histocompatibility antigens. In: Weir DM, ed. Handbook of Experimental Immunology. Oxford: Blackwell, 1978:1-20.

12 Compston DAS, Vakarelis BN, Paul E, McDonald W, Batchelor JR, Mims CA. Viral infection in patients with multiple sclerosis and HLA-DR matched controls. Brain 1986;109:325-44.

13 Sullivan CB, Visscher BR, Detels R. Multiple sclerosis and age at exposure to childhood disease and animals: cases and their friends. Neurology 1984;34:114-8. 